NBER WORKING PAPER SERIES

\title{
DOES AUTOMATIC ENROLLMENT INCREASE CONTRIBUTIONS TO SUPPLEMENT RETIREMENT PROGRAMS BY K-12 AND UNIVERSITY EMPLOYEES?
}

\author{
Robert L. Clark \\ Denis Pelletier \\ Working Paper 26263 \\ http://www.nber.org/papers/w26263 \\ NATIONAL BUREAU OF ECONOMIC RESEARCH \\ 1050 Massachusetts Avenue \\ Cambridge, MA 02138 \\ September 2019
}

\begin{abstract}
We would like to thank Rob Wylie, Executive Director of the South Dakota Retirement System, and his team for providing the administrative data used in this analysis. They also provided useful information about the introduction of automatic enrollment into the 457 plan. We also acknowledge the assistance of Joshua Franzel on earlier work describing the adoption of automatic enrollment in South Dakota. This project received funding from the TIAA Institute and the Wharton School's Pension Research Council/Boettner Center. The content is solely the responsibility of the authors and does not necessarily represent official views of the above-named institutions, nor of the National Bureau of Economic Research.
\end{abstract}

NBER working papers are circulated for discussion and comment purposes. They have not been peer-reviewed or been subject to the review by the NBER Board of Directors that accompanies official NBER publications.

(C) 2019 by Robert L. Clark and Denis Pelletier. All rights reserved. Short sections of text, not to exceed two paragraphs, may be quoted without explicit permission provided that full credit, including $\odot$ notice, is given to the source. 
Does Automatic Enrollment Increase Contributions to Supplement Retirement Programs by

K-12 and University Employees?

Robert L. Clark and Denis Pelletier

NBER Working Paper No. 26263

September 2019

JEL No. J14,J26,J45

\begin{abstract}
This study examines the impact of the adoption of automatic enrollment provisions by schools and universities in the state of South Dakota for its supplemental retirement saving plan (SRP). In South Dakota, educational personnel are also covered by a defined benefit pension plan and by Social Security. Thus, career public employees in South Dakota can expect a life time annuity from these two programs of around 75 percent of their final salary. Prior to the introduction of automatic enrollment, the proportion of newly hired educators who were contributing to the SRP was less than two percent in their first year of employment. After the introduction of automatic enrollment, over 90 percent of newly hired workers who were auto enrolled were participating in the plan. Thus, auto enrollment is shown to have the same powerful impact on contributions to a retirement saving plan for educational employees even when they also can expect life annuities from a defined benefit pension plan.
\end{abstract}

Robert L. Clark

Poole College of Management

Box 7229

North Carolina State University

Raleigh, NC 27695

and NBER

robert_clark@ncsu.edu

Denis Pelletier

Dept of Economics

North Carolina State University

Raleigh, NC 27695-8110

denis_pelletier@ncsu.edu 
Public education employees, at both the K-12 and university levels, tend to be covered by Social Security, defined benefit retirement plans, and many are also covered by retiree health plans offered by state and local government agencies. In addition, to being mandatorily covered by these plans, education personnel are also given the opportunity to participate in supplemental retirement plans which are retirement saving plans that receive preferential tax treatment. State governments usually allow educational employees to contribute to 457 or $401(\mathrm{k})$ plans. Many school districts and universities also offer employees the ability to contribute to 403(b) plans that often are managed at the local level. In contrast to $401(\mathrm{k})$ plans in the private sector, most public retirement saving plans do not offer employer matching contributions. An interesting policy question is whether educational employees covered by relatively generous retirement benefits and who are not offered employer matching contributions in the voluntary retirement savings plan as an enticement to participate in a voluntary retirement saving plan will react in the same manner to automatic enrollment provision as private sector employees who are not covered by other retirement benefits and often are covered by substantial employer matching contributions.

In general, career educational personnel earn a relatively generous lifetime annuity from their pension to augment an inflation-indexed annuity from Social Security and they often receive subsidized health insurance. With this base level of well-being in retirement, do teachers, professors, and other educational employees also contribute to employer provided retirement saving plans that do not provide the enticement of employer matching contributions? There is very little data on participation rates in these saving plans by public employees but the limited evidence indicates that participation rates are quite low. Two studies of North Carolina K-12 employees indicated that only about one third of all employees contribute to any supplemental saving plan (Clark, et al., 2016; Clark, Pathak, and Pelletier, 2018). 
Is the percentage of public employees who contribute to such saving plans based on optimal lifecycle decisions? An alternative explanation could be that public employees suffer from the effects of inertia in the same manner of employees who work for private sector firms, i.e. newly hired workers who are not automatically enrolled in the plan are have lower participation rates compare to those that are auto enrolled. Studies in behavioral economics indicate that framing has a substantial effect of choices and often the default is taken to as an implicit recommendation by the employer on whether additional saving is needed.

Over the past two decades, a series of papers have shown the power of defaults to alter saving decisions in employer-provided retirement saving plans. Studies have shown that automatic enrollment policies result in a substantial increase in the proportion of employees participating in retirement saving plans. In general, these studies have been conducted using administrative data for a single firm or a small set of private sector firms in which the retirement saving plan is the only employer-provided pension plan. The analysis typically focuses on the introduction of automatic enrollment to an existing 401(k) and compares participation and contributions rate shortly before and a few months after the adoption of the policy.

The present study examines the impact of the adoption automatic enrollment provisions for the 457 plan offered to educational employees by the state of South Dakota. South Dakota K-12 school employees along with employees of the university system are covered by a defined benefit pension plan and by Social Security. Thus, career educational employees can expect a lifetime annuity from these two programs of around 75 percent of their final salary. ${ }^{1}$ Prior to the

\footnotetext{
${ }^{1}$ Educational personnel in South Dakota are covered by the South Dakota Retirement System (SDRS) and they are also covered by Social Security. SDRS is a defined benefit pension plan with a benefit formula:

Benefit $=1.55 \%$ times (final average salary) times (years for service after 2008)
} 
introduction of automatic enrollment, the proportion of newly hired educational employees who were contributing to the supplemental retirement plan (SRP) was less than two percent in their first year of employment. After the introduction of automatic enrollment, over 90 percent of newly hired education personnel who were auto enrolled were participating in the SRP.

\section{Review of the Default Literature}

The recent literature examining the importance of defaults in supplemental retirement savings plans begins with Madrian and Shea (2001) who analyze the 401(k) savings behavior of employees in one large corporation before and after the introduction of automatic enrollment. The employer match in the plan was 50 percent on the first 6 percent of an employee's salary before and after the change in enrollment. The 401(k) plan was the only retirement plan offered by the firm. Prior to the adoption of automatic enrollment, the participation rate in the 401(k) plan was 57 percent. Auto enrollment was adopted by the firm in 1998 with a default contribution of 3 percent of salary. The result of automatic enrollment was that participation increased to over 80 percent and default contribution rate was a strong determinant of actual contributions. Similar results are reported by Choi, et al (2004) and Choi, Laibson, and Madrian (2004) who also examine employee responses to the introduction of automatic enrollment in a

plus

Benefit $=1.7 \%$ times (final average salary) times (years for service before 2008)

Individuals can retire with unreduced benefits at age 65 or if they meet the Rule of 85 requirements (the sum of the retiree's age plus years of service equal 85) and are at least age 55. A variable Cost Of Living Adjustment is provided based on the SDRS funded status and rate of inflation. The SDRS benefits summarized above are applicable to members hired before 2017 and details are described in the member handbook of the system which can be accessed at http://www.sdrs.sd.gov/docs/ClassAFoundationMemberHandbook.pdf 
variety of companies. In each case, they find that in the absence of automatic enrollment participation rates are rather low but increase with tenure. ${ }^{2}$

Most of the papers examine the response to automatic enrollment in 401(k) plans offered by private sector firms where the plan sponsor has an employer match and does not offer any other retirement plan. Thus compared to public employees, these private sector employees have a greater need to contribute to the saving plan and also the employer matching contribution provide a significant inducement to participate in the plan. The present study examines whether automatic enrollment will have similar powerful effects for public employees who are also covered by a defined benefit plan and when the employer does not provide an employer matching contribution.

\section{Adoption of Automatic Enrollment in South Dakota}

In July 2009, South Dakota became one of the first state government to adopt an automatic enrollment policy for its supplemental savings plan after the state legislature gave state and local agencies covered by the South Dakota Retirement System (SDRS) the authority to institute automatic enrollment policies; however, agencies were not required to adopt this policy. The legislation required that agencies that did adopt automatic enrollment must cover all newly hired employees. New employees in those agencies that adopted this policy are automatically enrolled

\footnotetext{
${ }^{2}$ An exception to the focus on private sector firms is Goda, et al (2018) which examines federal employees and participation in the Thrift Saving Plan (TSP). In additional to being able to contribute to the optional TSP, federal employees are also covered by a defined benefit plan and Social Security. This study reports a participation rate over 90 percent before the adoption of automatic enrollment and a subsequent small increase in participation after its adoption.
} 
in the SRP at a default contribution of $\$ 25$ per month (about one percent of the mean salary of South Dakota public employees). ${ }^{3}$ Each K-12 school district was treated as a separate agency for adopting automatic enrollment. As we shall see, some districts adopted automatic enrollment into the SRP while others did not. In contrast, all universities governed by The Board of Regents represented a single agency. Thus, when The Board of Regents chose to adopt the automatic enrollment policy, all employees in this system were automatically enrolled into the SRP.

The initial contributions to the SRP are placed in a money market account, for first 90 days after which time funds are transferred to an age appropriate target date fund. The participant can allocate these contributions to other investment options anytime during this 90-day window as well. Once automatically enrolled in the SRP, the participant has the option to increase contributions up to IRS maximum limits, move current and future contributions to other investment options, and within the first 90 days of being automatically enrolled, opt out of the SRP and receive a refund of all contributions. Once this 90-day window has past, future contributions can be stopped, i.e. the employee can opt out of the SRP; however, the participant cannot receive a refund of initial contributions unless they are eligible for a one-time, in-service distribution under IRS rules, are separated from service, or retire.

\section{Educational Institutions and Employee Characteristics}

This analysis will consider the impact of automatic enrollment by K-12 school districts in South Dakota and by the university system in the state. There are several major differences in these two educational sectors in South Dakota. First, all of the public universities in the state are

\footnotetext{
${ }^{3}$ Clark, Franzel, and Pelletier (2018) provide a detailed description of the automatic enrollment provisions and the process by which this policy was adopted and introduced.
} 
governed by The Board of Regents and all employees are provided the same benefits. In contrast, each school districts is an independent employer and is able to set some of its own employment and compensation rules including whether to adopt automatic enrollment. Second, as Table 1 shows, employees in the two sectors differ on two important characteristics. Males are considerably more prevalent in the university system compared to the public school system. Men represent almost half of the employees at universities but only a quarter of employees in the schools. In terms of annual pay, university employees average about 60 percent higher earnings compare to the annual earnings of school employees. Because of these important differences, we present enrollment data on participants in the SRP separately for the two educational groups. In this section, we briefly describe the two educational sectors in South Dakota.

[Table 1]

\section{Public School Employees}

We received data on 153 school districts in South Dakota in which employees are covered by the SDRS. The Department of Education website indicates that there are approximately 10,000 certified instructional staff in the SD school system. ${ }^{4}$ Teachers and other school personnel are state employees and thus, are covered by the state retirement system SDRS. Each employee is covered by the defined benefit retirement plan and Social Security. Each employee may choose to make contributions to a 457 plan (referred to in this paper as the SRP) that is managed by SDRS through a contract with Nationwide Retirement Solutions, Inc. Beginning in July 2009, the state authorized each state agency to decide whether it wanted to adopt automatic enrollment for new hires. Each school district is viewed as a separate employing agency and was able to decide whether to establish an automatic enrollment policy

\footnotetext{
${ }^{4}$ For more details on K-12 public schools in South Dakota, see the website https://doe.sd.gov/
} 
for the supplemental retirement plan (SRP). Only 13 of the districts decided to adopt automatic enrollment for the SRP.

Each district also has the ability to offer a 403(b) retirement saving plan to its employee. Public schools in the United States have long offered 403(b) plans to their employees. Across the country, school districts tend to manage their own 403(b) plans. A characteristic of these plans is that they usually allow a large number of vendors to participate in the plan. It is likely that history of 403(b) plans in K-12 schools is one of the reasons that most of the districts did not adopt automatic enrollment into the state-managed SRP. ${ }^{5}$ Unfortunately we do not have information on the 403 (b) plans offered by all of the school districts nor do we have data on the proportion of employees contributing the 403(b) plans. ${ }^{6}$

\section{University Employees}

Public institutions of higher education in South Dakota are governed by The South Dakota Board of Regents. The Board determines compensation policies for the six universities and two special schools that are governed by The Board of Regents. The following institutions are included in the system: University of South Dakota, South Dakota State University, South Dakota School of Mines and Technology, Northern State University, Black Hills State University, Dakota State University, South Dakota School for the Visually Impaired, and South

\footnotetext{
${ }^{5}$ See Clark and Hanson (2013) for an overview of 403(b) plans in public schools in all 50 states.

${ }^{6}$ The 403(b) plans are described on the websites of some of the school districts. For example, the Souix Falls district website describes both state-managed 457 plan and district's 403(b) plan. Souix Falls did not adopt a policy of automatic enrollment in the 457 plan managed by the SDRS and does not have such a policy for its own 403(b). The district's 403(b) plan is managed by TSA consulting group and the plan has 17 vendors who are allowed to offer plans for school employees. http://insite.sf.k12.sd.us/images/docs/Benefits/benefits_at_a_glance/Benefits_2018-2019.pdf\#page=28
} 
Dakota School for the Deaf; the Regents also set personnel for The Board of Regents Central Office. The system employs approximately 5,100 employees. Compensation and benefits are governed, in part, by a collective bargaining agreement between The Board of Regents and the Council of Higher Education, an affiliate of South Dakota Education Association and the National Education Association.

Employees in these institutions are covered by SDRS and Social Security. In addition, employees have the opportunity to contribute to the SDRS-managed SRP. For the purpose of considering adopting the automatic enrollment policy, all institutions in the system were considered a single government agency. The Board chose to institute automatic enrollment in 2009, therefore, after this date all new employees in all of the institutions were automatically enrolled in the SRP.

University employees can also contribute to a 403(b) plan that is managed by The Board. There are also no matching employer contributions to this plan and the plan does not include a Roth option for post-tax contributions. The following 10 vendors have been approved to offer tax sheltered annuities through this plan: TIAA, American Funds, AIG, Ameriprise, Waddell and Reed, New York Life, Fidelity, Vanguard, Horace Mann, and AXA Equitable. Employees can make contributions to both the 457 plan and the 403(b) up to the maximum allowed by federal legislation. $^{7}$

\section{Changes in Participation Rates in Response to the Adoption of Automatic Enrollment}

\footnotetext{
${ }^{7}$ Information on the 457 and 403(b) plans is provided on the website of member institutions. An example of the information provided by the member institutions is shown in the Appendix for the University of South Dakota.
} 
To examine the impact of the introduction of automatic enrollment in the SRP, we obtained administrative records from SDRS on all employees by public schools and universities in South Dakota who were hired between 2005 and 2016. Using these data, we are able to determine enrollment rates for all new hires in the first year of employment and the subsequent participation rates between the hire date and 2016. The data are reported by fiscal years. In this section, we report the changes in participation in the SRP before and after 2010 when automatic enrollment was adopted. The analysis reported separately for K-12 schools and the universities.

\section{Annual Participation Rates with and without Auto Enrollment: Public Schools}

The administrative records allow us to observe the year each employee was hired and whether the new employee contributed to the SRP in their first year of employment. Participation is measured by annual contributions at the end of the fiscal year. In Column 1, Table 2 reports the number of new hires by year and annual hires range between 1,284 and 2,833. Columns 2 and 3 sort new hires into individuals whose school district had adopted auto enrollment and those districts where auto enrollment was not adopted. Prior to 2010, automatic enrollment was not allowed so no district auto enrolled any new employees. Column 4 reports the percent of all new employees enrolled in the SRP by year of employment. The participation rate in the SRP for educational employees hired between 2005 and 2009 was less than two percent in each year. ${ }^{8}$

\footnotetext{
${ }^{8}$ Remember that these school employees also had the opportunity to contribute to district-managed 403(b) plans so that the participation rate for contributions to any retirement saving plan will be larger than the rate for the SRP only. Clark, et al. (2016) reported a participation rate for all North Carolina K12 employees of approximately 30 percent with less than half of these participants in the state-managed 401(k) or 457 plans compared to more than half contributing to the district-managed 403(b) plans.
} 


\section{[Table 2]}

The introduction of automatic enrollment into the SRP produced a change in saving outcomes. After the new law went into effect, participation rates in the SRP for all new hires jumped from less than two percent to over 12 percent. This increase understates the impact of the adoption of automatic enrollment by those actually covered by the new policy. As we noted earlier, only 13 districts adopted auto enrollment so most of the new hires were by districts that maintained the old opt-in policy. Column 5 indicates the percent of individuals hired after 2009 who were automatically enrolled in the SRP and who remained in the plan during their first year of employment was over 90 percent. In comparison, Column 6 shows the percent of individuals who enrolled in the SRP and were not subject to automatic enroll remained less than five percent in every year. This comparison shows that the districts that adopted auto enrollment had participation rates of 90 percent higher compared to the districts that did not adopt this policy.

It is interesting to note that the participation rate of 90 percent with automatic enrollment observed in South Dakota is very similar to the participation rate found in studies of private sector firms that do not provide their employees with a defined benefit plan and whose 401(k) plans offer employer matches. The low rate of opting out of the SRP supports the finding of earlier studies that inertia plays a substantial role in the effect of automatic enrollment. In addition, the low opt-out rate by school employees may also be influenced by the relatively low default contribution rate of only \$25 per month or about 1 percent of average salary for school personnel which raises the question did the new employees even notice the modest reduction in their take home pay due to the default contribution. The change in participation rates in South Dakota indicate that even when employees have relatively high replacement rates from a defined 
benefit pension plan and Social Security automatic enrollment in a retirement saving plan produces participation rates of 90 percent.

\section{Are There Lasting Effects of Automatic Enrollment for School Employees?}

In order to determine the long-range impact of automatic enrollment on participation in retirement saving plans, one needs several years of employment data to see whether participation rates with automatic enrollment decline over time. Similarly, one needs to determine if participation rates rise over time without automatic enrollment. If rates decline relative to year of hire for those automatically enrolled and rise for those without automatic enrollment, then limiting the analysis of year of hire rates would overstate the positive impact of adopting automatic enrollment. To examine these issues, we sort the observations by year of employment and whether the employer adopted automatic enrollment. Next, we calculate the proportion of individuals by hire year who are contributing to the SRP for each year between year of hire and 2016. Participation rates between hire date and 2016 for those with and without automatic enrollment are shown in Table 3 by year of hire.

[Table 3]

The proportion of workers contributing to the SRP among those automatically enrolled steadily declines with additional years of employment. For those hired in 2010 who were auto enrolled, the participation rate fell from 95.2 percent in year of hire to 80.9 percent in 2016 . Similarly for those hired in 2012, the year of employment rate was 95.3 percent and this rate declined to 87.5 percent in 2016. Thus, the proportion of school personnel contributing to the SRP who were auto enrolled fell noticeably in the first years of employment. In contrast, the 
participation rates for those not automatically enrolled tended to rise slightly with additional years of service. But still the gap between the two groups remains large. The decline in the proportion of employees contributing to the SRP who were auto enrolled might indicate that some of these individuals were choosing to return to the 403(b) plans offered by the district.

\section{Annual Participation Rates with and without Auto Enrollment: Universities}

We now present similar data on SRP enrollments for employees in institutions covered by The Board of Regents. As before, the administrative records allow us to observe the year each employee was hired and whether the new employee contributed to the SRP in that first year. Table 4 reports the number of new employees hired each year. The annual number of university hires range between 475 and 711. The Board of Regents adopted auto enrollment for all institutions effective August 23, 2009. Thus, no employees were automatically enrolled in years 2005-2009 and then all were auto enrolled in subsequent years. Since our data reflect enrollment for the fiscal year, new employees hired in 2009 between July 1 and August 22 were not automatically enrolled while all individuals hired after that date were. Therefore, the data for fiscal year 2010 include both individuals who were auto enrolled and some that were not. The annual participation rate in the SRP for university employees hired before 2010 was less than 2.2 percent. With automatic enrollment, the participant rate exceeds 94 percent for persons hired in every year.

[Table 4]

During the opt-in period, first year enrollments in the SRP were extremely low with only around two percent of new hires enrolling in the SRP. In the first years of employment, there 
were small annual increases in the proportion of the university employees who contributed to the SRP. In contrast, the participation rate declines by 3 to 6 percent per year for those who were auto enrolled. It is interesting to note that participation rates in the SRP with auto enrollment exceed 90 percent even though these university employees also have the opportunity to contribute to locally managed 403(b) plans. We are unable to determine whether the increased contributions to the SRP are net new contributions or they reflect reductions in the contributions to the educational institutions managed 403(b) plans.

\section{[Table 5]}

\section{Determinants of Participation with and without Auto Enrollment}

Using the administrative data from South Dakota, we examine factors that influence contributions to the SRP before and after the adoption of auto enrollment. In the following analysis, we estimate participation rates in the SRP using a single probit model for employees in K-12 school districts and in the university system. Specifically, we estimate the probability of new hires making contributions to the SRP in their first year of employment whether they were automatically enrolled in the SRP or whether the new employee was not automatically enrolled. An interesting aspect of this analysis is that in the automatic enrollment years, some school districts adopted automatic enrollment and others did not. Thus, we are able to examine participation decisions for individuals in different school districts some with and some without automatic enrollment in the same year. Since all institutions covered by The Board of Regents adopted auto enrollment at the same time, this step in our analysis can only be done for the K-12 school districts. For institutions that did adopt auto enrollment, we are able to estimate participation decisions before and after the policy is adopted. 
As with other studies that use administrative data, we have limited information about the personal characteristics of new hires. The data provided by the SDRS include the age of employees when first employed (measured in years), whether the employee is a female or male, the annual salary (measured in thousands of dollars), the specific state agencies that employed the individual, whether the employee was auto-enrolled in the SRP, and when the employer adopted auto-enrollment if it ever did. Using these data, we estimate participation decisions of K-12 and university employees.

Using the complete sample of all new employees hired over the years 2005-2016, we estimate the probability that an employee participates in the SRP in the year of hire. The analysis for employees of K-12 schools and for university employees is done jointly, while allowing the impact of the different explanatory variables to vary between the two groups. ${ }^{9}$ The model includes the following explanatory variables: age at hire, a dichotomous variable equal to one if the employee is a male and zero if not, annual salary in first year of employment (measured in thousands of dollars), a dichotomous variable equal to one if the employee was auto-enrolled and hired by a school district and zero if not, a dichotomous variable equal to one if the employer is a school district that adopted auto-enrollment and zero if not, and year of employment fixed effects. To capture the change that took place mid-year in fiscal year 2010 for the university system, we introduce two dummies for that one year. The first dummy (2010-) is equal to one if the individual was hired between July 1, 2009 and August 23, 2009, and equal to zero otherwise. The second dummy variable (2010+) covers the rest of the fiscal year (August

\footnotetext{
${ }^{9}$ Explanatory variables are introduced twice, once multiplied by a dichotomous variable equal to one if the individual is a school employee and zero otherwise, a second time as multiplied by a dichotomous variable equal to one if the individual is a university employee and zero otherwise.
} 
24, 2009 to June 30, 2010). The marginal effects derived from the probit equation are shown in Table 6. We discuss the results in various contexts.

[Table 6]

Participation in SRP in First Year of Employment for School Employees: 2005 to 2016

Column 1, Table 6 reports the partial effects evaluated at the mean of the sample for the employees of the public schools. The age effect indicates that each additional 10 years of age increases the probability of contributing to the SRP by 0.9 percentage points. The probability that a new male hire will participate is about 1.1 percentage points lower than a corresponding female hire but this difference is not statistically significant. A $\$ 10,000$ higher initial salary increases the probability of participation by 3 percentage points. One should remember that during first half of the sample period, participation rates were very low so these small percentage point increases represent substantial percentage increases in the pre-auto enroll period.

Whether the employee was auto-enrolled into the SRP dramatically increases the probability of making a contribution to the SRP in the first year of employment. The probability of participation in the year of employment is 90 percentage points higher for those who were auto enrolled compared to those who were not. Whether the employer eventually adopts autoenrollment also has an important impact, increasing the probability of participation by 6.3 percentage points. This finding suggests that districts where employees had a higher propensity to contribute to the SRP were more likely to adopt auto enrollment. Holding constant whether the individual was automatically enrolled in the SRP, the year fixed effects indicate that the overall participation rate trends up during the years after auto enrollment was adopted.

An alternative way to interpret the estimates from the probit model is to compute the predicted probabilities of participating in the SRP for different scenarios. For example, let us 
consider the estimates of the probit model and the following stylized new hire by a school district: a 37 year old female earning $\$ 30,000$. If this individual was hired in 2006 from a district who never adopted auto-enrollment, the predicted probability of participating in the SRP is 1.22 percent, increasing to 2.74 percent if hired in 2011 instead. In 2006, if the employer is one who will eventually adopt auto-enrollment once it becomes available, then the probability is 2.67 percent. Finally, if this individual was hired in 2011 and auto-enrolled then the probability is 96.69 percent.

Participation in SRP in First Year of Employment for University Employees: 2005 to 2016

Next, we examine the impact of adopting auto enrollment by The Board of Regents so that all new employees hired by the universities were enrolled in the SRP. Columns 3 and 4 of Table 6 show the partial effects and corresponding standard errors from the probit model for participation for newly hired university employees. For these employees, age and gender have no significant impact, economically or statistically. The impact of salary for university hires is about half the impact for school hires, a $\$ 10,000$ higher salary raises the probability of participation by about 1.5 percentage points.

Since all new hires by the university system became auto-enrolled after August 23, 2009 we cannot introduce employee and employer auto-enroll dichotomous variables as well as year fixed effects. This would create perfect multicollinearity. The impact of adopting autoenrollment in this case is fully and directly captured by the year fixed effects. Looking at the results we see that by going from 2009 to 2010+ (the second part of the fiscal year, after the adoption of auto-enrollment), the probability of participation increases by about 94.6 percentage points, this being the difference between the two partial effects). This in a sense captures the impact of a new hire being auto-enrolled and being in a period where new hires can be auto- 
enrolled. We note that for university hires the magnitude of the year dummies are much larger than for new public school hires; it's simply because they now also include the employee and employer auto-enroll variables.

Also of interest is the partial effect for the Year dummy 2010-. It's a much larger value than for the years 2006 to 2009, 56.8 percent compared to 1-2 percent. Yet, it’s for a period where auto-enrollment had not yet been adopted. Looking at the raw numbers, of the 185 new hires by the university system between July 1, 2009 and August 23, 2009, 103 participated in SRP. This suggest that during this period new hires were made aware of this upcoming change and more than half decided to enroll.

\section{Adoption of auto-enrollment policy by school districts}

Finally, we examine the decision by school districts whether or not to adopt the autoenrollment into SRP for new hires. For 144 of the school districts we were able to collect information about the numbers of students, the average salary and the number of instructional personal (measured as full time equivalent, FTE). The information is for 2016. Descriptive statistics are reported in Table 7. We see that there are large differences in all these variables across school districts. Looking at averages over the quintiles, we see a difference of about $\$ 9,000$ in average salary comparing the $1^{\text {st }}$ and $5^{\text {th }}$ quintiles. There is a lot of variations in the size of the school districts, with the difference between the average over the $1^{\text {st }}$ and $5^{\text {th }}$ quintiles equal to about 3,000 students. For the number of students per instructional FTE, the difference between the average over the $1^{\text {st }}$ quintile and the $5^{\text {th }}$ quintile is over 7 students per FTE, corresponding to an almost doubling of the ratio.

[Table 7] 
We investigate if these school districts characteristics can be associated to their decision to adopt or not auto-enrollment in the SRP. In Table 8, we present results from a probit model where the dependent variable is a dichotomous variable equal to one if the school district has adopted auto-enrollment by the end of our sample, otherwise it is zero. We use as explanatory variables dichotomous variables for the quintiles of the three variables in Table 7 (average salary, number of students, students per instructional FTE). We include quintile dummies instead of the variables themselves and their squares to better be able to capture nonlinearities in the impact of these variables on the adoption of auto-enrollment by the school districts. Despite allowing for a lot of flexibility, our results suggest that nothing clearly explains why a school district would adopt auto-enrollment. Our estimates indicate for example that school districts in the top three quintiles of average salary are about 13 percentage points less likely to adopt autoenrollment than those in the first two quintiles. But these estimates have very large standard errors so we can't rule out that they are zero. The results are similar for the number of students. For the number of students per instructional FTE, only school districts in the $5^{\text {th }}$ quintile statistically stand out, being about 47 percentage points more likely to adopt auto-enrollment than those in the first quintile. But taken jointly, we cannot reject a null hypothesis that all these partial effects are equal to zero. The value of the LR test for this hypothesis is 7.60 with a pvalue equal to 0.81 (the asymptotic distribution is chi-square with 12 degrees of freedom).

[Table 8]

\section{Conclusions}

There is a considerable literature indicating the effectiveness of automatic enrollment policies in increasing participation in retirement saving plans. Virtually all of these studies examine private sector firms where a 401(k) plan is the only retirement plan offered by the 
employer. We are not aware of any previous study examining the impact of introducing automatic enrollment on the participation rates of K-12 and university personnel in a supplemental retirement saving plan.

In general, all public full-time employees are covered by a mandatory pension, usually a defined benefit plan. As a result, career public employees that are also covered by Social Security are likely to have a life annuity equal to 70-80 percent of their final salary. While government employers offer their employees the opportunity to contribute to a retirement saving plan, employees may believe that they have less of a need for additional retirement saving. In addition, the plans offered by government employers rarely have matching employer contributions so there is less of an incentive for employees to contribute to these plans.

As a result, participation rates in retirement saving plans in the public sector tend to be much lower than they are for private sector firms. In our example, only about 2 percent of newly hired K-12 and university employees in South Dakota enrolled in the 457 plan offered to state and local employees prior to 2010. The objective of this study is to determine whether K-12 and university employees in South Dakota responded to the introduction of an automatic enrollment policy at the same level as private sector employees.

The key finding of this analysis is that participation rates in the retirement saving plan by university personnel go from less than 2 percent to 90 percent after the introduction of automatic enrollment. The richness of the data provided by the SDRS allows us to explore several interesting issues. A unique component of the data is that South Dakota allowed each government agency to adopt automatic enrollment in 2010 but the agencies were not required to adopt this policy. Each school district made its own decision on whether to adopt auto enrollment while the Board of Regents made the decision for all of its institutions. As a result of these 
decisions by educational institution, we can compare the change in participation over time for the same agencies before and after the introduction of auto-enrollment and also to compare employees hired in agencies with and without auto-enrollment in the same year. All of the comparisons indicate that the introduction of automatic enrollment yield increases in participation rates of newly hired K-12 and university employees of over 80 percent.

Another difference in the automatic enrollment policy in South Dakota is that relatively low default contribution rate of $\$ 25$ per month, or approximately one percent of the average salary of a new employee. This low default contribution may partially explain the large response to the auto-enrollment policy.

This study shows that K-12 and university employees who are covered by a defined benefit plan and Social Security tend not to contribute to a traditional opt-in retirement saving plan; however, the adoption of automatic enrollment for new employees results in a dramatic increase in the proportion of employees who participate in the plan. Across country, public employers are reducing the generosity of their retirement plans. As a result, the findings from this study have important policy implications and indicate that K-12 and universities should consider the adoption of automatic enrollment policies to encourage participation in the supplement saving plans to enhance the retirement security of public employees. 


\section{References}

Choi, James, David Laibson, and Brigitte Madrian. 2004. "Plan Desing and 401(k) Savings Outcomes,” National Tax Journal, LVII (2): 275-298.

Choi, James J., David Laibson, Brigitte C. Madrian, and Andrew Metrick. 2004. "For Better or for Worse: Default Effects and 401 (k) Savings Behavior." Perspectives on the Economics of Aging, David Wise (ed.). Chicago: University of Chicago Press, pp. 81126.

Clark, Robert, Joshua Franzel, and Denis Pelletier. 2018. "Impact of Automatic Enrollment in the 457 Plan for South Dakota Public Employees,” Center for State and Local Government Excellence. https://slge.org/publications/impact-of-automatic-enrollment-in-the-457-planfor-south-dakota-public-employees

Clark, Robert and Emma Hanson. 2013. “403b Plans for Public School Teachers: How They Are Monitored and Regulated in Each State,” Research Dialogue No. 103, TIAA Institute. https://www.tiaainstitute.org/sites/default/files/presentations/201702/107b.pdf

Clark, Robert, Emma Hanson, Melinda Morrill, and Aditi Pathak. 2016. “Supplemental Plan Offerings and Retirement Saving Choices: An Analysis of North Carolina School Districts,” Journal of Pension Economics and Finance, 15(3): 333-355.

Clark, Robert, Aditi Pathak, and Denis Pelletier. 2018. "Supplemental Retirement Savings Plans in the Public Sector: Participation and Contribution Decisions by School Personnel,” Journal of Labor Research, 39(4): 383-404.

Clark, Robert and Denis Pelletier. 2019. “Impact of Defaults in Retirement Savings Plans: Public Employee Plans,” unpublished working paper.

Goda, Gopi Shah, Marthew Levy, Colleen Flaherty Manchester, Aaron Sououner, and Joshua Tasoff. 2018. "Mechanisms Behind Retirement Saving Behavior: Evidence from Administrative and Survey Data,” Research Dialogue No. 140, TIAA Institute, February.

Madrian, Brigitte, and Dennis Shea. 2001. "The Power of Suggestion: Inertia in 401(k) Participation and Savings Behavior.” Quarterly Journal of Economics, 66 (4): 1149-88. 
Table 1. Sample Means of Employee Characteristics: Public School and University Employees

\begin{tabular}{|c|l|l|}
\hline & $\begin{array}{l}\text { Public school } \\
\text { employees } \\
\mathbf{( 1 )}\end{array}$ & $\begin{array}{l}\text { University } \\
\text { employees } \\
\mathbf{( 2 )}\end{array}$ \\
\hline Age at hire & & $37.15^{* *}$ \\
\hline Full sample & 37.52 & $37.88^{* * *}$ \\
\hline Before 2010 & 38.85 & 36.71 \\
\hline 2010 and after & 36.76 & \\
\hline Male & & $47.10 \%^{* * *}$ \\
\hline Full sample & $25.98 \%$ & $47.56 \%^{* * *}$ \\
\hline Before 2010 & $26.60 \%$ & $46.82 \%^{* * *}$ \\
\hline 2010 and after & $25.63 \%$ & \\
\hline Salary & & $\$ 39,606^{* * *}$ \\
\hline Full sample & $\$ 24,434$ & $\$ 36,009^{* * *}$ \\
\hline Before 2010 & $\$ 22,772$ & $\$ 41,772^{* * *}$ \\
\hline 2010 and after & $\$ 25,381$ & \\
\hline
\end{tabular}

This table reports the sample average for important employee characteristics before and after the adoption of automatic enrollment. Columns 1 and 2 respectively split the sample into new hires by public schools or universities. The symbols ${ }^{*},{ }^{* *}$, and ${ }^{* * *}$ indicate that the difference between the values in columns 2 are statistically different than the corresponding value in column 1 at the $10 \%, 5 \%$, and $1 \%$ significance level respectively. 
Table 2. Proportion of Public School Employees Contributing to SRP in First Year of Employment.

\begin{tabular}{|l|l|l|l|l|l|l|}
\hline $\begin{array}{l}\text { Fiscal } \\
\text { year } \\
\text { of } \\
\text { hire }\end{array}$ & $\begin{array}{l}\text { Number } \\
\text { of new } \\
\text { hires by } \\
\text { year } \\
(1)\end{array}$ & $\begin{array}{l}\text { Number of } \\
\text { hires who } \\
\text { were } \\
\text { automatically } \\
\text { enrolled } \\
(2)\end{array}$ & $\begin{array}{l}\text { Number of } \\
\text { hires who } \\
\text { were not } \\
\text { automatically } \\
\text { enrolled } \\
(3)\end{array}$ & $\begin{array}{l}\text { Percent } \\
\text { of hires } \\
\text { enrolled } \\
\text { in SRP } \\
(4)\end{array}$ & $\begin{array}{l}\text { Percent of } \\
\text { hires who } \\
\text { were } \\
\text { automatically } \\
\text { enrolled who } \\
\text { are in the } \\
\text { SRP } \\
(5)\end{array}$ & $\begin{array}{l}\text { Percent of } \\
\text { hires not } \\
\text { automatically } \\
\text { enrolled who } \\
\text { are in the } \\
\text { SRP } \\
(6)\end{array}$ \\
\hline $\mathbf{2 0 0 5}$ & 1284 & N/A & 1284 & 0.86 & N/A & 0.86 \\
\hline $\mathbf{2 0 0 6}$ & 1398 & N/A & 1398 & 1.36 & N/A & 1.36 \\
\hline $\mathbf{2 0 0 7}$ & 1684 & N/A & 1684 & 0.71 & N/A & 0.71 \\
\hline $\mathbf{2 0 0 8}$ & 1926 & N/A & 1926 & 1.09 & N/A & 1.09 \\
\hline $\mathbf{2 0 0 9}$ & 1849 & N/A & 1849 & 1.57 & N/A & 1.57 \\
\hline $\mathbf{2 0 1 0}$ & 1520 & 167 & 1353 & 12.37 & 95.21 & 2.14 \\
\hline $\mathbf{2 0 1 1}$ & 1503 & 217 & 1286 & 15.70 & 99.08 & 1.63 \\
\hline $\mathbf{2 0 1 2}$ & 1525 & 171 & 1354 & 12.59 & 95.32 & 2.14 \\
\hline $\mathbf{2 0 1 3}$ & 2107 & 334 & 1773 & 17.80 & 97.90 & 2.71 \\
\hline $\mathbf{2 0 1 4}$ & 2300 & 319 & 1981 & 15.65 & 95.93 & 2.73 \\
\hline $\mathbf{2 0 1 5}$ & 2621 & 381 & 2240 & 17.47 & 96.33 & 4.06 \\
\hline $\mathbf{2 0 1 6}$ & 2833 & 419 & 2414 & 18.29 & 96.18 & 4.76 \\
\hline
\end{tabular}

This table reports the participation rate in the SRP in the first year of employment for different year of hire cohorts, considering only public school employees. The participation rate is computed as the number of individuals hired in a given fiscal year, with positive earnings in the designated year, and who made a positive contributions divided by the number of individuals who were hired in this fiscal year and who had positive annual earnings in their first year. 
Table 3. Participation Rate by Year of Hire with and without Automatic Enrollment for public school employees

\begin{tabular}{|c|c|c|c|c|c|c|c|c|c|c|c|c|c|}
\hline \multicolumn{2}{|c|}{ Year of hire } & 2005 & 2006 & 2007 & 2008 & 2009 & 2010 & 2011 & 2012 & 2013 & 2014 & 2015 & 2016 \\
\hline 2005 & & 0.86 & 1.87 & 1.99 & 2.54 & 3.42 & 3.79 & 3.98 & 3.17 & 3.57 & 4.00 & 4.19 & 4.25 \\
\hline 2006 & & & 1.36 & 1.48 & 1.94 & 3.23 & 3.92 & 3.68 & 4.04 & 3.81 & 4.87 & 5.57 & 6.38 \\
\hline 2007 & & & & 0.71 & 1.13 & 1.92 & 1.98 & 2.69 & 3.38 & 3.61 & 4.24 & 5.09 & 6.05 \\
\hline 2008 & & & & & 1.09 & 1.29 & 2.05 & 2.42 & 2.61 & 2.91 & 3.71 & 4.23 & 4.96 \\
\hline 2009 & & & & & & 1.57 & 1.79 & 2.03 & 2.46 & 2.82 & 2.88 & 3.36 & 4.18 \\
\hline 2010 & & & & & & & 12.37 & 12.07 & 11.35 & 10.85 & 12.09 & 12.62 & 12.84 \\
\hline 2010 & $\begin{array}{l}\text { with } \\
\text { auto }\end{array}$ & & & & & & 95.21 & 87.10 & 83.97 & 80.37 & 80.00 & 80.44 & 80.95 \\
\hline 2010 & $\begin{array}{l}\text { w/o } \\
\text { auto }\end{array}$ & & & & & & 2.14 & 2.54 & 1.97 & 2.21 & 3.06 & 3.29 & 3.45 \\
\hline 2011 & All & & & & & & & 15.70 & 14.09 & 13.69 & 14.68 & 15.14 & 15.86 \\
\hline 2011 & $\begin{array}{l}\text { with } \\
\text { auto }\end{array}$ & & & & & & & 99.08 & 94.51 & 92.52 & 92.91 & 93.04 & 92.59 \\
\hline 2011 & $\begin{array}{l}\text { w/o } \\
\text { auto }\end{array}$ & & & & & & & 1.63 & 1.47 & 1.57 & 2.36 & 2.65 & 3.21 \\
\hline 2012 & All & & & & & & & & 12.59 & 11.38 & 11.77 & 11.59 & 11.97 \\
\hline 2012 & $\begin{array}{l}\text { with } \\
\text { auto }\end{array}$ & & & & & & & & 95.32 & 91.67 & 89.74 & 87.63 & 87.50 \\
\hline 2012 & $\begin{array}{l}\text { w/o } \\
\text { auto }\end{array}$ & & & & & & & & 2.14 & 1.68 & 2.61 & 3.19 & 4.15 \\
\hline 2013 & All & & & & & & & & & 17.80 & 16.20 & 16.50 & 15.82 \\
\hline 2013 & $\begin{array}{l}\text { with } \\
\text { auto }\end{array}$ & & & & & & & & & 97.90 & 94.10 & 94.30 & 92.27 \\
\hline 2013 & $\begin{array}{l}\text { w/o } \\
\text { auto }\end{array}$ & & & & & & & & & 2.71 & 2.85 & 3.34 & 4.01 \\
\hline 2014 & All & & & & & & & & & & 15.65 & 13.54 & 13.14 \\
\hline 2014 & $\begin{array}{l}\text { with } \\
\text { auto }\end{array}$ & & & & & & & & & & 95.93 & 94.16 & 91.50 \\
\hline 2014 & $\begin{array}{l}\text { w/o } \\
\text { auto }\end{array}$ & & & & & & & & & & 2.73 & 1.96 & 2.56 \\
\hline 2015 & All & & & & & & & & & & & 17.47 & 14.49 \\
\hline 2015 & $\begin{array}{l}\text { with } \\
\text { auto }\end{array}$ & & & & & & & & & & & 96.33 & 91.75 \\
\hline 2015 & $\begin{array}{l}\text { w/o } \\
\text { auto }\end{array}$ & & & & & & & & & & & 4.06 & 2.72 \\
\hline 2016 & All & & & & & & & & & & & & 18.29 \\
\hline 2016 & $\begin{array}{l}\text { with } \\
\text { auto }\end{array}$ & & & & & & & & & & & & 96.18 \\
\hline 2016 & $\begin{array}{l}\text { w/o } \\
\text { auto }\end{array}$ & & & & & & & & & & & & 4.76 \\
\hline
\end{tabular}


Table 4. Proportion of University Employees Contributing to SRP in First Year of Employment.

\begin{tabular}{|l|l|l|l|l|l|l|}
\hline $\begin{array}{l}\text { Fiscal } \\
\text { year } \\
\text { of } \\
\text { hire }\end{array}$ & $\begin{array}{l}\text { Number } \\
\text { of new } \\
\text { hires by } \\
\text { year } \\
(1)\end{array}$ & $\begin{array}{l}\text { Number of } \\
\text { hires who } \\
\text { were } \\
\text { automatically } \\
\text { enrolled } \\
\text { (2) }\end{array}$ & $\begin{array}{l}\text { Number of } \\
\text { hires who } \\
\text { were not } \\
\text { automatically } \\
\text { enrolled } \\
(3)\end{array}$ & $\begin{array}{l}\text { Percent } \\
\text { of hires } \\
\text { enrolled } \\
\text { in SRP } \\
(4)\end{array}$ & $\begin{array}{l}\text { Percent of } \\
\text { hires who } \\
\text { were } \\
\text { automatically } \\
\text { enrolled who } \\
\text { are in the } \\
\text { SRP } \\
(5)\end{array}$ & $\begin{array}{l}\text { Percent of } \\
\text { hires not } \\
\text { automatically } \\
\text { enrolled who } \\
\text { are in the } \\
\text { SRP } \\
(6)\end{array}$ \\
\hline $\mathbf{2 0 0 5}$ & 507 & N/A & 507 & 0.79 & N/A & 0.79 \\
\hline $\mathbf{2 0 0 6}$ & 488 & N/A & 488 & 1.43 & N/A & 1.43 \\
\hline $\mathbf{2 0 0 7}$ & 536 & N/A & 536 & 1.49 & N/A & 1.49 \\
\hline $\mathbf{2 0 0 8}$ & 547 & N/A & 547 & 2.19 & N/A & 2.19 \\
\hline $\mathbf{2 0 0 9}$ & 532 & N/A & 532 & 2.07 & N/A & 2.07 \\
\hline $\mathbf{2 0 1 0}$ & 475 & 290 & 185 & 79.79 & 95.17 & 55.68 \\
\hline $\mathbf{2 0 1 1}$ & 497 & 497 & 0 & 97.99 & 97.99 & N/A \\
\hline $\mathbf{2 0 1 2}$ & 653 & 653 & 0 & 94.18 & 94.18 & N/A \\
\hline $\mathbf{2 0 1 3}$ & 647 & 647 & 0 & 97.68 & 97.68 & N/A \\
\hline $\mathbf{2 0 1 4}$ & 644 & 644 & 0 & 98.14 & 98.14 & N/A \\
\hline $\mathbf{2 0 1 5}$ & 654 & 654 & 0 & 94.65 & 94.75 & N/A \\
\hline $\mathbf{2 0 1 6}$ & 711 & 711 & 0 & 96.84 & 96.84 & N/A \\
\hline
\end{tabular}

This table reports the participation rate in the SRP in the first year of employment for different year of hire cohorts, considering only university employees. The participation rate is computed as the number of individuals hired in a given fiscal year, with positive earnings in the designated year, and who made a positive contribution divided by the number of individuals who were hired in this fiscal year and who had positive annual earnings in their first year. 
Table 5. Participation Rate by Year of Hire with and without Automatic Enrollment for university employees

\begin{tabular}{|c|c|c|c|c|c|c|c|c|c|c|c|c|c|}
\hline \multicolumn{2}{|c|}{ Year of hire } & 2005 & 2006 & 2007 & 2008 & 2009 & 2010 & 2011 & 2012 & 2013 & 2014 & 2015 & 2016 \\
\hline 2005 & & 0.79 & 1.12 & 2.40 & 3.81 & 4.35 & 6.02 & 6.39 & 7.58 & 6.82 & 6.71 & 8.11 & 7.81 \\
\hline 2006 & & & 1.43 & 2.75 & 4.40 & 5.18 & 4.07 & 5.39 & 5.29 & 5.43 & 5.92 & 5.84 & 5.48 \\
\hline 2007 & & & & 1.49 & 2.27 & 2.13 & 3.75 & 4.59 & 4.03 & 4.89 & 5.83 & 7.07 & 8.48 \\
\hline 2008 & & & & & 2.19 & 2.83 & 4.19 & 4.27 & 5.84 & 8.03 & 6.82 & 8.63 & 9.34 \\
\hline 2009 & & & & & & 2.07 & 4.45 & 5.10 & 6.16 & 6.76 & 6.90 & 9.46 & 10.55 \\
\hline 2010 & & & & & & & 79.79 & 68.39 & 68.17 & 67.13 & 69.67 & 70.23 & 70.37 \\
\hline 2010 & $\begin{array}{l}\text { with } \\
\text { auto }\end{array}$ & & & & & & 95.17 & 81.98 & 80.46 & 78.95 & 80.14 & 79.23 & 77.88 \\
\hline 2010 & $\begin{array}{l}\text { w/o } \\
\text { auto }\end{array}$ & & & & & & 55.68 & 44.79 & 48.15 & 50.00 & 54.08 & 56.47 & 59.21 \\
\hline 2011 & All & & & & & & & 97.99 & 83.60 & 80.75 & 81.75 & 81.56 & 79.54 \\
\hline 2011 & $\begin{array}{l}\text { with } \\
\text { auto }\end{array}$ & & & & & & & 97.99 & 83.60 & 80.75 & 81.75 & 81.56 & 79.54 \\
\hline 2011 & $\begin{array}{l}\text { w/o } \\
\text { auto }\end{array}$ & & & & & & & $\mathrm{NaN}$ & $\mathrm{NaN}$ & $\mathrm{NaN}$ & $\mathrm{NaN}$ & $\mathrm{NaN}$ & $\mathrm{NaN}$ \\
\hline 2012 & All & & & & & & & & 94.18 & 82.67 & 81.45 & 80.76 & 82.00 \\
\hline 2012 & $\begin{array}{l}\text { with } \\
\text { auto }\end{array}$ & & & & & & & & 94.18 & 82.67 & 81.45 & 80.76 & 82.00 \\
\hline 2012 & $\begin{array}{l}\text { w/o } \\
\text { auto }\end{array}$ & & & & & & & & $\mathrm{NaN}$ & $\mathrm{NaN}$ & $\mathrm{NaN}$ & $\mathrm{NaN}$ & $\mathrm{NaN}$ \\
\hline 2013 & All & & & & & & & & & 97.68 & 88.57 & 86.11 & 86.16 \\
\hline 2013 & $\begin{array}{l}\text { with } \\
\text { auto }\end{array}$ & & & & & & & & & 97.68 & 88.57 & 86.11 & 86.16 \\
\hline 2013 & $\begin{array}{l}\text { w/o } \\
\text { auto }\end{array}$ & & & & & & & & & $\mathrm{NaN}$ & $\mathrm{NaN}$ & $\mathrm{NaN}$ & $\mathrm{NaN}$ \\
\hline 2014 & All & & & & & & & & & & 98.14 & 86.42 & 84.84 \\
\hline 2014 & $\begin{array}{l}\text { with } \\
\text { auto }\end{array}$ & & & & & & & & & & 98.14 & 86.42 & 84.84 \\
\hline 2014 & $\begin{array}{l}\text { w/o } \\
\text { auto }\end{array}$ & & & & & & & & & & $\mathrm{NaN}$ & $\mathrm{NaN}$ & $\mathrm{NaN}$ \\
\hline 2015 & All & & & & & & & & & & & 94.65 & 89.12 \\
\hline 2015 & $\begin{array}{l}\text { with } \\
\text { auto }\end{array}$ & & & & & & & & & & & 94.65 & 89.12 \\
\hline 2015 & $\begin{array}{l}\text { w/o } \\
\text { auto }\end{array}$ & & & & & & & & & & & $\mathrm{NaN}$ & $\mathrm{NaN}$ \\
\hline 2016 & All & & & & & & & & & & & & 96.48 \\
\hline 2016 & $\begin{array}{l}\text { with } \\
\text { auto }\end{array}$ & & & & & & & & & & & & 96.48 \\
\hline 2016 & $\begin{array}{l}\text { w/o } \\
\text { auto }\end{array}$ & & & & & & & & & & & & $\mathrm{NaN}$ \\
\hline
\end{tabular}


Table 6. Probit Model for Individual Participation in the SRP in Year of Hire for Public School and University Employees

\begin{tabular}{|l|c|c|c|c|}
\cline { 2 - 5 } \multicolumn{1}{c|}{} & \multicolumn{2}{|c|}{ Public School Employees } & \multicolumn{2}{c|}{ University Employees } \\
\cline { 2 - 5 } \multicolumn{1}{c|}{} & Partial Effects & PE Std. Errors & Partial Effects & PE Std. Errors \\
\hline Age at hire & $0.091^{* * *}$ & 0.026 & 0.000 & 0.047 \\
\hline Male & -1.099 & 0.728 & -0.041 & 1.083 \\
\hline Salary & $0.300^{* * *}$ & 0.014 & $0.152^{* * *}$ & 0.016 \\
\hline Employee auto-enroll & $90.977^{* * *}$ & 2.227 & & \\
\hline Employer auto-enroll & $6.324^{* * *}$ & 1.568 & & 4.440 \\
\hline Year dummy 2006 & 0.490 & 2.411 & 0.911 & 4.278 \\
\hline Year dummy 2007 & -0.299 & 2.582 & 1.176 & 4.124 \\
\hline Year dummy 2008 & 0.263 & 2.401 & 2.102 & 4.196 \\
\hline Year dummy 2009 & 1.015 & 2.306 & 1.646 & 3.830 \\
\hline Year dummy 2010- & 2.642 & 2.510 & $56.807^{* * *}$ & 4.248 \\
\hline Year dummy 2010+ & 1.566 & 2.907 & $96.241^{* * *}$ & 4.412 \\
\hline Year dummy 2011 & 2.429 & 2.449 & $97.804^{* * *}$ & 3.907 \\
\hline Year dummy 2012 & 2.441 & 2.288 & $95.257^{* * *}$ & 4.318 \\
\hline Year dummy 2013 & $3.701^{*}$ & 2.175 & $97.636^{* * *}$ & 4.385 \\
\hline Year dummy 2014 & 3.155 & 2.123 & $97.897^{* * *}$ & 3.980 \\
\hline Year dummy 2015 & $4.505^{* *}$ & 2.065 & $95.617^{* * *}$ & $96.771^{* * *}$ \\
\hline Year dummy 2016 & $5.487^{* * *}$ & 2.024 & & \\
\hline
\end{tabular}

Marginal effects are calculated at the mean values based on probit estimates of participation. Statistical significance: $10 \%(*), 5 \%(* *)$ and 1\% (***). The variables Year dummy 2010 - and Year dummy 2010+ are dichotomous variables equal to 1 if the observation is during the period July 1, 2009-August 22, 2009 or August 23, 200-June 30, 2010 respectively. The LR test (pvalue) for the hypothesis that all interaction terms are zero is $99.14(0.000)$. The Wald test (pvalue) for the hypothesis that the interaction terms cancel out the regressors in the auto-enroll era is 102.21 (0.000). The number of observations is 22550. The fraction of individuals who participate in the SRP is $10.73 \%$. The standard errors of the partial effects are calculated with the Delta method. The variable $I_{2010}$ represents a dummy variable equal to one if the observation is in year 2010 or later, otherwise it's equal to zero. 
Table 7. Descriptive statistics of School Districts Characteristics

\begin{tabular}{|c|c|c|c|}
\hline & Average salary & Number of students & $\begin{array}{c}\text { Number of students } \\
\text { per instructional } \\
\text { FTE }\end{array}$ \\
\hline $\begin{array}{c}* * \text { Full sample } \\
\text { average }\end{array}$ & $\$ 38,870$ & 929.88 & 12.08 \\
\hline $1^{\text {st }}$ quintile average & $\$ 34,504$ & 150.52 & 8.28 \\
\hline $2^{\text {nd }}$ quintile average & $\$ 36,963$ & 245.90 & 10.49 \\
\hline $3^{\text {rd }}$ quintile average & $\$ 38,551$ & 347.32 & 12.08 \\
\hline $4^{\text {th }}$ quintile average & $\$ 40,086$ & 595.48 & 13.74 \\
\hline $5^{\text {th }}$ quintile average & $\$ 43,666$ & 3290.10 & 15.82 \\
\hline
\end{tabular}

This table reports descriptive statistics for some school districts characteristics: average salary, number of students and number of students per instructional FTE. We report full sample averages as well as sample averages over five quartiles. The total number of school districts in this analysis is 144 . 
Table 8. Probit estimates for school districts adoption of auto-enrollment

\begin{tabular}{|c|c|c|}
\hline & Partial effect & Standard error \\
\hline Average salary & & \\
\hline $2^{\text {nd }}$ quintile average & -1.18 & 7.67 \\
\hline $3^{\text {rd }}$ quintile average & -13.70 & 13.26 \\
\hline $4^{\text {th }}$ quintile average & -13.49 & 11.09 \\
\hline $5^{\text {th }}$ quintile average & -14.36 & 12.28 \\
\hline Number of students & & \\
\hline $2^{\text {nd }}$ quintile average & -12.85 & 10.64 \\
\hline $3^{\text {rd }}$ quintile average & -0.08 & 7.96 \\
\hline $4^{\text {th }}$ quintile average & -12.10 & 14.93 \\
\hline $5^{\text {th }}$ quintile average & -6.99 & 9.86 \\
\hline $\begin{array}{c}\mathbf{N b} \text {. students per } \\
\text { inst. FTE }\end{array}$ & & \\
\hline $2^{\text {nd }}$ quintile average & 1.87 & 14.86 \\
\hline $3^{\text {rd }}$ quintile average & 16.30 & 11.56 \\
\hline $4^{\text {th }}$ quintile average & 22.60 & 12.72 \\
\hline $5^{\text {th }}$ quintile average & $46.83^{* * *}$ & 14.43 \\
\hline
\end{tabular}

This table reports partial effects evaluated at the mean for a probit model where the dependent variable is the decision of a school district to adopt auto-enrollment. The explanatory variables are dichotomous variables corresponding to quintiles of average salary, number of students and number of students per instructional FTE. The number of observations is 144 and 11 school districts adopted auto-enrollment. We left out the $1^{\text {st }}$ quintile so the interpretation of the partial effects are deviations from the $1^{\text {st }}$ quintile. The value of the Likelihood ratio test for the null hypothesis that all parameters are equal to zero except for the intercept is equal to 7.60 with a corresponding p-value equal to 0.81 . Statistical significance: $10 \%\left(^{*}\right), 5 \%\left({ }^{* *}\right)$ and $1 \%\left(^{* * *}\right)$. 


\section{Appendix}

Statement on University of South Dakota website concerning the SRP managed by SDRS.

https://www.usd.edu/-/media/files/human-resources/retirementtranscript.ashx?la=en

“The Supplemental Retirement Plan is another retirement option that you are automatically enrolled in. You are initially set up to have a \$25 deduction from your paycheck, and that deduction will be invested in conservative investment options selected by the SD Investment Council. This contribution is not matched by USD. The deduction amount and the investment option for this plan can be changed at any time. You also have the option to Opt-Out within 90 days and receive a refund of those contributions. However, if you do make any changes during the opt-out period, you void your right to opt-out and will not receive a refund. You will need to contact Supplemental Retirement at the number listed to request the Opt-Out form or to make changes to your contribution... Along with the Supplemental Retirement contribution, you also have the option to contribute on a Post-Tax basis to a Roth (457B) plan through Supplemental Retirement. Subject to restrictions, the distribution of earnings may be taken out tax-free.”

\section{Statement on University of South Dakota website concerning the Tax Sheltered Annuities offered by the Board of Regents.}

Another option for retirement saving "is a Tax Sheltered Annuity or 403B plan. As an eligible employee, you are able to participate in the 403B Plan through Retirement Manager. There are different plan vendors including Fidelity, New York Life, TIAA CREF, and Vanguard. The 403b contributions are not matched by USD. You may set up your 403b at any time through the Retirement Manager.” 